EDUKACJA MIĘDZYKULTUROWA

2013, nr 2

ISSN 2299-4106

Justyna Jabeeka, Irena Kubak

\title{
Koło Naukowe Edukacji Międzykulturowej jako przykład dobrego połączenia studenckiej praktyki z akademicką teorią
}

Streszczenie: Koło Naukowe Edukacji Międzykulturowej (KNEM) to studencka organizacja działająca nieprzerwanie od 2003 roku w Uniwersytecie Śląskim, na Wydziale Etnologii i Nauk o Edukacji w Cieszynie. Aktualnie na Uniwersytecie Śląskim zarejestrowane są 183 koła naukowe, z czego 6 na Wydziale Etnologii i Nauk o Edukacji w Cieszynie, w tym właśnie Koło Naukowe Edukacji Międzykulturowej. Pomysłodawczyniami stworzenia KNEM były Alina Szczurek-Boruta oraz Barbara Grabowska, które zostały opiekunkami naukowymi koła.

Koło Naukowe Edukacji Międzykulturowej realizuje projekty o zróżnicowanym charakterze oraz zakresie tematycznym. Projekty te mają charakter edukacyjny, naukowy, społeczny i kulturalny. Działalność koła obejmuje liczne konferencje naukowe (konferencje poruszające problematykę rodzicielstwa zastępczego, opieki paliatywnej, tolerancji, stereotypów, innych kultur i narodów), warsztaty edukacyjne (tematyką nawiązujące np. do tolerancji, Praw Człowieka, międzykulturowości, twórczości i kreatywności), działania woluntarystyczne (wolontariat w szpitalu na oddziałach dziecięcych), jak również udział jego członków w różnego rodzaju szkoleniach i wymianach o charakterze krajowym czy międzynarodowym (wymiana polsko-litewska, warsztaty polsko-niemiecko-białoruskie). Nie brakuje także przedsięwzięć stricte rozrywkowych (Międzynarodowy Dzień Sąsiada, imprezy taneczne o charakterze folklorystycznym). Studenckie Koło Naukowe Edukacji Międzykulturowej znakomicie łączy akademicką teorię z praktyką.

Słowa kluczowe: studencki ruch naukowy, edukacja międzykulturowa

\section{Wprowadzenie}

Koło Naukowe Edukacji Międzykulturowej (KNEM) to studencka organizacja działająca na Uniwersytecie Śląskim w Wydziale Etnologii i Nauk o Edukacji w Cieszynie. Koło istnieje już prawie dziesięć lat, a jego działalność od samego początku budziła zainteresowanie wśród studentów pedagogiki i etnologii. Również wielu pracowników akademickich podjęło współpracę i oka- 
zało aprobatę w stosunku do działań studenckich. Liczne wykłady, konferencje, wyjazdy, warsztaty to tylko część przedsięwzięć podejmowanych przez członków KNEM. W niniejszym artykule postaramy się przybliżyć historię, wydarzenia naukowe i społeczno-artystyczne oraz inne ciekawe fakty i plany związane z działalnością Koła Naukowego Edukacji Międzykulturowej.

\section{Krótka historia}

Trzy lata po powołaniu Uniwersytetu Śląskiego w Katowicach tj. w 1971 roku, powstała filia Uniwersytetu Śląskiego zlokalizowana w Cieszynie. 4 października tego roku naukę w cieszyńskiej filii rozpoczęło 140 studentów. Kadra naukowo-dydaktyczna filii liczyła 2 samodzielnych i 13 młodszych pracowników ${ }^{1}$. Cieszyn stał się miejscem dużej aktywności i działalności studenckiej. Jeszcze w tym samym roku, w którym powstaje filia, zostaje powołany do życia studencki zespół chóralny pod kierownictwem Władysława Wilczaka, który cieszy się dużą popularnością w Polsce i poza jej granicami. Rok później przybiera nazwę Towarzystwa Śpiewaczego „Harmonia”. W 1975 roku w cieszyńskiej filii istniało już 8 kół naukowych (Muzyczne Koło Naukowe, SKN Plastyków, Wokalno-Instrumentalny Zespół Muzyki Dawnej, SKN Folklorystów, SKN Pedagogiki Społecznej, SKN Wychowania harcerskiego, SKN Psychologów oraz Zespół Teatralny ATRIUM) ${ }^{2}$. W tym samym roku w Katowicach i Sosnowcu było zarejestrowanych 20 kół naukowych. Łącznie koła naukowe zrzeszały $6 \%$ studentów całej uczelni ${ }^{3}$.

Aktualnie na Uniwersytecie Śląskim zarejestrowane są 183 koła naukowe, z czego 6 na Wydziale Etnologii i Nauk o Edukacji w Cieszynie ${ }^{4}$. Wśród nich swą działalnością może poszczycić się Koło Naukowe Edukacji Międzykulturowej. Pierwsze spotkanie założycielskie osób zainteresowanych przyszłą działalnością koła odbyło się 26 listopada 2003 roku. Na spotkaniu tym usta-

1 A. Barciak: Wyrósł z dobrego drzewa... Uniwersytet Ślaski 1968-1998. Fakty, dokumenty, relacje. Katowice 1998, UŚ, s. 22.

2 L. Czuchajowski: Studencki Ruch Naukowy w Uniwersytecie Ślaskim. „Biuletyn Informacyjny Uniwersytetu Śląskiego", Katowice maj 1976, s. 19-27.

3 A. Barciak: Wyróst z dobrego drzewa... Uniwersytet Ślaski 1968-1998. Fakty, dokumenty, relacje. cyt. wyd., s. 22, 29.

4 Dane pochodzące z dokumentacji Działu Spraw Studenckich, ul Bankowa 12A, Katowice. 
lono program oraz regulamin działalności organizacji $i^{5}$. Pomysłodawczyniami stworzenia KNEM w Cieszynie były Alina Szczurek-Boruta oraz Barbara Grabowska, które zostały opiekunkami naukowymi koła. O przyczynach zaangażowania się studentów w proces kształtowania się i działalność organizacji można przeczytać już na pierwszej stronie kroniki: „do uczestnictwa w tym kole niewątpliwie skłonił nas fakt, że nasza uczelnia znajduje się na pograniczu polsko-czeskim" - piszą studenci ${ }^{6}$. Chęć poznania i badania różnorodności kultur oraz szerzenia postawy otwartości na Inność sprawiły, że w dniu 8 stycznia 2004 roku złożono wniosek o rejestrację koła do Działu Organizacyjno-Prawnego Uniwersytetu Śląskiego w Katowicach. Decyzją Prorektora ds. Kształcenia - prof. dr. hab. Wojciecha Świątkiewicza 20 stycznia 2004 roku Koło Naukowe Edukacji Międzykulturowej formalnie rozpoczęło działalność na terenie Uniwersytetu Śląskiego, zostało wpisane do rejestru kół naukowych ${ }^{7}$. KNEM nieprzerwanie istnieje do dnia dzisiejszego, zmieniają się tylko jego członkowie, zapraszani goście, rodzaje działań, ale potrzeba upowszechniania edukacji międzykulturowej pozostaje niezmienna.

\section{Najważniejsze działania członków KNEM}

Koło Naukowe Edukacji Międzykulturowej realizuje projekty o zróżnicowanym charakterze oraz zakresie tematycznym. Ich dobór jest uzależniony od pasji i preferencji samych członków koła, ale nie można pominąć faktu, iż członkowie koła starają się także zauważać potrzeby środowiska lokalnego. Projekty te mają charakter edukacyjny, naukowy, społeczny i kulturalny. Adresowane są one zarówno do studentów cieszyńskich wydziałów ${ }^{8}$, jak i do dzieci, uczniów szkół podstawowych, gimnazjalistów i licealistów cieszyńskich placówek oświatowych, czy też do osób dorosłych i pracujących zawodowo.

Działalność koła obejmuje zatem liczne konferencje naukowe, warsztaty edukacyjne, działania woluntarystyczne, jak również udział jego członków w różnego rodzaju szkoleniach i wymianach o charakterze krajowym czy międzynarodowym. Nie brakuje także przedsięwzięć o charakterze stricte rozrywkowym.

5 Dokumentacja KNEM.

6 Kronika KNEM (2003 - nadal).

7 Dokumentacja KNEM.

8 W cieszyńskim ośrodku akademickim działają dwa wydziały: Wydział Artystyczny i Wydział Etnologii i Nauk o Edukacji. 
Ważnym elementem działania koła jest współpraca z różnymi instytucjami, stowarzyszeniami i organizacjami działającymi nie tylko na terenie Cieszyna. Współpraca ta skupia się głównie na organizacji imprez okolicznościowych: mikołajki, bale karnawałowe czy andrzejki w przedszkolach i szkołach, a także m.in. na udziale członków koła w charakterze wychowawców kolonii i realizacji programu edukacyjnego nawiązującego do tematyki edukacji międzykulturowej. Nie brakuje warsztatów o różnej tematyce realizowanych w placówkach oświatowych czy instytucjach kulturalnych (np. biblioteka). Członkowie koła i inni zainteresowani tematyką studenci mogli także zostać wolontariuszami w projekcie realizowanym przez Koło Naukowe Edukacji Międzykulturowej w Szpitalu Wojewódzkim w Cieszynie, na oddziałach dziecięcym i chirurgii dziecięcej ${ }^{9}$.

Dużą popularnością wśród studentów cieszą się warsztaty edukacyjne, czyli forma spotkania, w czasie którego sa przekazywane praktyczne umiejętności ${ }^{10}$. Warsztaty przeprowadzane są przez członków koła czy przez zapraszanych przez nich pracowników naukowych bądź specjalistów w danej dziedzinie. Studenci, także ci, którzy do koła nie należą, mogli do tej pory uczestniczyć w warsztatach o różnej tematyce, na przykład dotyczących: tolerancji, międzykulturowości, praw człowieka, metod i twórczych technik pracy z dziećmi, jak również $\mathrm{w}$ warsztatach, na których były przedstawione zróżnicowane techniki plastyczne $^{11}$.

Członkowie koła podejmowali się także przeprowadzania dni tematycznych. Działania tego typu to między innymi Międzynarodowy Dzień Sąsiada czy Międzynarodowy Dzień Tolerancji. Oba te projekty były połączone z konkursami plastycznymi kierowanymi do dzieci i młodzieży cieszyńskich szkół. Z kolei sami studenci, którzy stanowili główną grupę docelową tych przedsięwzięć, mogli na terenie campusu uczestniczyć we wszelkiego rodzaju konkursach oraz czynnościach i działaniach nawiązujących tematyką do danego dnia ${ }^{12}$.

Członkowie KNEM w ciągu prawie dziewięciu lat istnienia koła zorganizowali dwadzieścia dwie konferencje naukowe, w tym dwie z nich to konferencje dwudniowe. Wszystkie te spotkania naukowe odbyły się w Centrum

9 Kronika KNEM (2003 - nadal).

10 Regulamin przyznawania środków finansowych dla organizacji studenckich przez Uczelnianą Radę Samorządu Studenckiego z puli środków na działalność studencką. Katowice 2005, s. 4.
11 Kronika KNEM (2003 - nadal).
12 Kronika KNEM (2003 - nadal). 
Konferencyjnym Wydziału Etnologii i Nauk o Edukacji Uniwersytetu Śląskiego w Cieszynie. Pierwsza konferencja odbyła się w drugim roku działalności koła, a mianowicie 27 kwietnia 2005 roku. Jako tematykę konferencji członkowie KNEM wybrali zagadnienia związane z tolerancją osób odmiennej narodowości, wyznania, zwrócono również uwagę na tolerancję wobec osób niepełnosprawnych. Konferencja nosiła tytuł Tolerancja - jak uczyć siebie i innych. Prelegentami konferencji byli zarówno praktycy, pracownicy naukowi, jak i studenci. Każda następna konferencja była wyjątkowa, niepowtarzalna i dotyczyła innej problematyki.

Na szczególną uwagę zasługuje cykl konferencji pt. Poznajmy Innego, w ramach którego zorganizowano sześć konferencji naukowych poświęconych zgłębieniu różnych kultur i narodowości m.in. Żydów, Niemców, Amerykanów, Francuzów, Czechów. Poruszano także zagadnienia związane z różnorodnością regionalną naszego kraju. Studenci zorganizowali Dni Góralskie oraz Dni Śląskie, w których ciekawe wykłady i prelekcje przeplatały się z bogatym repertuarem kulturalno-rozrywkowym. W czasie ich trwania można było „zakosztować" prawdziwego folkloru, zjeść tradycyjne potrawy, posłuchać ludowych opowiadań przekazywanych z pokolenia na pokolenie. „Sięgając ciekawym okiem” poza nasz kontynent, studenci z KNEM zaprosili także gości, którzy podczas konferencji „Różne oblicza Afryki” zaprezentowali cienie i blaski tego kontynentu.

Członkowie koła zorganizowali szereg konferencji, których tematyka poszerzała typowe obszary edukacji wielo- i międzykulturowej, ilustrowała zróżnicowane indywidualne zainteresowania studentów, dotyczące wielorakich problemów społecznych naszego kraju. Do tej grupy spotkań naukowych można zaliczyć konferencje na temat opieki paliatywnej, rodzicielstwa zastępczego czy też innych form opieki nad dzieckiem, zagadnień związanych z wolontariatem, a nawet zdrowego odżywiania lub opieki nad zwierzętami. Wartym zauważenia jest fakt, iż większość z nich była wzbogacona o wydarzenia towarzyszące, w tym przedstawienia teatralne, warsztaty edukacyjne czy projekcje filmowe.

Organizacja konferencji to jedna z wielu form aktywności studenckiej cieszyńskich członków KNEM. Należy jednak wspomnieć, że wiedzę i bogate doświadczenia związane $\mathrm{z}$ ich przygotowaniem zdobywali, uczestnicząc w licznych konferencjach naukowych, odbywających się zarówno w miejscowym wydziale, jak i w innych ośrodkach akademickich. Nierzadko członkowie koła gościli na konferencjach nie tylko po to, by zdobywać cenną wiedzę, ale również by podzielić się własną. Stawianie pierwszych kroków na polu 
działań naukowych, wcielanie się w role prelegentów czy moderatorów było także bardzo kształcące. Po licznych wystąpieniach studenckich pozostały teksty naukowe, opublikowane i nieopublikowane, referaty, znajdują się one w dokumentacji archiwalnej koła, a także na stronie internetowej ${ }^{13}$ oraz w różnych publikacjach naukowych ${ }^{14}$.

\section{Współpraca międzynarodowa}

Cieszyński ośrodek akademicki leży na pograniczu polsko-czeskim. To właśnie jego położenie w dużej mierze przyczyniło się do powstania opisywanego koła naukowego zgłębiającego tematykę wielo- i międzykulturowości, jak i do podjęcia owocnej współpracy z placówkami czeskimi, takimi jak Slezská univerzita v Opavé czy Szkoła Podstawowa z Polskim Językiem Nauczania w Czeskim Cieszynie. Prócz kontaktów z zaprzyjaźnionymi Czechami studenci uczestniczyli także w konferencji w Bańskiej Bystrzycy, nawiązując kontakty ze Słowakami. Kilkakrotnie za pomocą połączenia internetowego prowadzili rozmowy ze studentami z El Camino Collage w Kalifornii, USA. Członkowie KNEM uczestniczyli także w międzynarodowych polsko-niemiecko-białoruskich warsztatach zorganizowanych w dwóch etapach we Wrocławiu oraz w Lipsku (24-28 listopada 2009, 20-28 listopada 2010). Podczas kilkudniowych zajęć uczestnicy poznali tradycje, sytuację polityczną poszczególnych państw, systemy edukacji uczestników wymiany, wymieniali poglądy, które ich łączyły i różniły.

Najbardziej owocnym i stricte studenckim międzynarodowym przedsięwzięciem studentów koła była Polsko-Litewska Wymiana Młodzieży Trudne rozmowy o Czesławie Miłoszu - dialog, tolerancja, partnerska wspótpraca (17-21 października 2011) ${ }^{15}$. Rozpisany projekt został nagrodzony w kon-

13 www.knem.us.edu.pl

14 Zob.: T. Gebel, K. Jas: Tolerancja przedmiotem studenckiej refleksji. „Wychowanie na co dzień” 2005, nr 9 (144), s. 27-28; K. Gebel: Poznajmy Innego, czyli jak polscy studenci postrzegaja inne narodowości. W: L. Kasacova (red.): Inovacne trendy v edukacnej teorii a praxi Banska. Bystrica 2007, Univerzity Mateja Bela, Banská Bystrica, s. 80-83; A. Gancarz: Studenckie Koło Naukowe Edukacji Międzykulturowej. W: L. Kasacova (red.): Inovacne trendy v edukacnej teorii a praxi. cyt. wyd., s. 77-80; I. Bielska: Poznaj innego. „Magazyn Studentów Uniwersytetu Śląskiego”, maj 2007, s. 8; A. Gancarz: Co znaczy dobra robota? „Po lekcjach”, Kraków 2009, zeszyt 34, s. 18-23.

15 http://knem.us.edu.pl/index.php?option=com_content\&view=category\&layo $\mathrm{ut}=$ blog\&id=65\&Itemid=95 (dostęp: 16.01.2013). 
kursie organizowanym przez Polsko-Litewski Fundusz Wymiany Młodzie$\dot{z} y^{16}$, który to jednocześnie podjął się jego sfinansowania. Przez blisko tydzień grupa studentów z Cieszyna mogła gościć studentów z Wilna. W tym czasie uczestnicy wymiany zwiedzali Cieszyn, Kraków, uczestniczyli w licznych warsztatach, spotkaniach, konferencjach, a także wydarzeniach rozrywkowych, takich jak między innymi wieczór kultur. Tematyka spotkań w dużej mierze nawiązywała do postaci Czesława Miłosza i jego twórczości. W ten sposób młodzież chciała włączyć się do międzynarodowych obchodów Roku Miłosza ustanowionego z okazji jego setnych urodzin. Studenci czytali poezję Czesława Miłosza, przygotowywali krótkie przedstawienia, inscenizacje do jego wierszy, jak również wychodzili z projektami edukacyjnymi do wybranych cieszyńskich szkół licealnych ${ }^{17}$. Wspólne działania, rozmowy, spacery przyczyniły się do nawiązania bliższych znajomości, przełamania barier i zweryfikowania istniejących stereotypów dotyczących naszych wschodnich sąsiadów. Współpraca międzynarodowa jest najlepszą formą budowania i szerzenia tolerancji.

\section{Zakończenie}

Koło Naukowe Edukacji Międzykulturowej ma na swoim koncie wiele ciekawych i godnych uwagi przedsięwzięć, nie jesteśmy w stanie opisać ich wszystkich szczegółowo, ponieważ jest to tematyka tak obszerna, że poświęcono jej trzy prace dyplomowe, a gdyby powstała nawet i czwarta, to temat nie byłby zamknięty.

Członkowie koła ciągle jednak szukają czegoś nowego i angażują się w różne projekty. Przykładem tego mogą być chociażby plany przeprowadzenia III edycji Wampiriady. Wampiriada to akcja honorowego krwiodawstwa przeprowadzana wśród studentów różnych uczelni wyższych w Polsce. Od 2011 roku z powodzeniem organizują ją także członkowie KNEM ${ }^{18}$.

Dodatkowo w planach na przyszły rok, a nawet na najbliższy semestr akademicki, znajdują swoje miejsce konferencje naukowe, które często są kontynuacją tematyki z wcześniejszych miesięcy. Z pewnością nie zabraknie

16 Projekt „Trudne rozmowy o Czesławie Miłoszu - tolerancja, dialog, partnerska współpraca" zarejestrowany pod numerem FPL1-065-2011 w dniu 11 kwietnia 2011 roku przez Komitet Polsko-Litewskiego Funduszu Wymiany Młodzieży.

17 Kronika KNEM (2003 - nadal).

18 Kronika KNEM (2003 - nadal). 
także warsztatów edukacyjnych, na których będzie można sprawdzić swoją kreatywność, zapoznać się z różnymi technikami pracy, które można wykorzystać w przyszłości, oraz przyswoić wiedzę książkową w praktyczny sposób, w otoczeniu ludzi pozytywnie nastawionych do działania.

Koło Naukowe Edukacji Międzykulturowej wypełnia wiele funkcji, jakie spełnia edukacja dla dorosłych. Bez wątpienia można wskazać tu ma funkcję integracyjną, popularyzacyjną, doskonalącą, wychowawczą, samokształcącą, samorealizacji, adaptacyjną, kompensacyjną, czy nawet profilaktyczną ${ }^{19}$. Działania koła świetnie uzupełniają się z akademicką teorią, a ich utrata byłaby wielką stratą dla braci studenckiej. Dokonania członków i opiekunów koła na długo pozostaną w pamięci żaków i pracowników uniwersytetu.

\section{Bibliografia}

Aleksander T.: Funkcje edukacji dorostych. „Edukacja Dorosłych” 1997, nr 1. Barciak A.: Wyróst z dobrego drzewa... Uniwersytet Ślaski 1968-1998. Fakty, dokumenty, relacje. Katowice 1998, UŚ.

Bielska I.: Poznaj innego. „Magazyn Studentów Uniwersytetu Śląskiego”, maj 2007.

Czuchajowski L.: Studencki Ruch Naukowy w Uniwersytecie Śląskim. „Biuletyn Informacyjny Uniwersytetu Śląskiego", Katowice maj 1976.

Dokumentacja Działu Spraw Studenckich, ul Bankowa 12A, Katowice.

Dokumentacja KNEM.

Gancarz A.: Co znaczy dobra robota? „Po lekcjach”, Kraków 2009, zeszyt 34.

Gancarz A.: Studenckie Koło Naukowe Edukacji Międzykulturowej. W: L. Kasacova (red.): Inovacne trendy v edukacnej teorii a praxi. Banska Bystrica 2007, Univerzita Mateja Bela Banská Bystrica.

Gebel K.: Poznajmy Innego, czyli jak polscy studenci postrzegaja inne narodowości. W: L. Kasacova (red.): Inovacne trendy v edukacnej teorii a praxi. Banska Bystrica 2007, Univerzita Mateja Bela Banská Bystrica.

Gebel T., Jas K.: Tolerancja przedmiotem studenckiej refleksji. „Wychowanie na co dzień" 2005, nr 9 (144).

Kronika KNEM.

19 T. Aleksander: Funkcje edukacji dorostych. „Edukacja Dorosłych” 1997, nr 1, s. $27-35$. 
Projekt „Trudne rozmowy o Czesławie Miłoszu - tolerancja, dialog, partnerska współpraca" zarejestrowany pod numerem FPL1-065-2011 w dniu 11 kwietnia 2011 r. przez Komitet Polsko-Litewskiego Funduszu Wymiany Młodzieży.

Regulamin przyznawania środków finansowych dla organizacji studenckich przez Uczelnianą Radę Samorządu Studenckiego z puli środków na działalność studencką. Katowice 2005.

www.knem.us.edu.pl

\section{The Science Club of Intercultural Education as an example of beneficial combination of student practice and academic theory}

\section{Summary}

The Science Club of Intercultural Education is a students' organization which has been active unceasingly since 2003 at the University of Silesia, in the Faculty of Ethnology and Education in Cieszyn. Currently, there are 183 registered science clubs at the University of Silesia, out of which 6 (including the Science Club of Intercultural Education) function within the above mentioned faculty. The idea to establish the club came from Dr Alina Szczurek-Boruta (now UŚ Professor) and Dr Barbara Grabowska, who became its research supervisors.

The Club implements projects of different (educational, scientific, social, cultural) nature and subject matter. The activity of the Club comprises: numerous academic conferences (on the issues of substitute parenthood, palliative care, tolerance, stereotypes, other cultures and nations), educational workshops (on e.g. tolerance, human rights, interculturalism, creation and creativity), voluntary activities (voluntary activity at hospital children wards), participation in various national and international training and exchange programmes (the Polish-Lithuanian exchange, the Polish-German-Belarussian workshops). Some entertainment undertakings take place as well (the International Day of Neighbour, folk dance events). The Science Club of Intercultural Education excellently combines academic theory and practice.

Key words: students' scientific movement, intercultural education 